\title{
Mixture of Crushed-Stone Aggregate as Material For Substructure Layers
}

https://doi.org/10.2478/sgem-2018-0014

received March 23, 2018; accepted May 29, 2018.

Abstract: One of the most important elements of road construction is its substructure, which constitutes the base on which the next layers of road are placed. Mixture of crushed-stone aggregate is very often used as material for substructure. The most frequently used type of aggregate is magma rocks, due to its good physicalmechanical properties. However, it is not always available, so it is substituted by sandstone or even concrete rubble aggregates. The bearing ratio $\mathrm{CBR}$ is a parameter determining the suitability of a certain aggregate for road substructure. It is also one of the most popular quality tests of aggregate as it does not require complex apparatus. This paper analyses the results of physical and geotechnical tests with particular focus on CBR bearing ratio of crushed aggregates and their application as substructure for road construction. There has also been an attempt to find the correlation between CBR bearing ratio and other physical and geometrical properties.

Keywords: mixture of crushed-stone aggregate; the California bearing ratio (CBR); road substructure.

\section{Introduction}

Soil and mixture of aggregates compaction is one of the methods of enhancing ground and road surface layers. The compaction results in an increase of the bearing capacity of particular layers of road surfaces in conditions similar to optimum moisture content and its consequence is a guarantee of proper work of construction without distortions/deformations complying requirements of particular road traffic rules. A basic test to evaluate soil or substructure bearing is CBR ratio test (California Bearing

\footnotetext{
*Corresponding author: Joanna Hydzik-Wiśniewska, AGH University of Science and Technology, Poland, E-mail: hydzik@agh.edu.pl Anna Wilk, tukasz Bednarek, Sebastian Olesiak: AGH University of Science and Technology, Poland
}

Ratio) [16,23]. Value of this bearing is a basis for planning thickness density of road surface layers. The method was developed for road and airfield surfaces in the 40s of the last century in the USA [2]. The advantages of designing roads and soil substructure based on CBR method is high compliance with thickness of existing that which are still in good condition. It does not require complicated apparatus and may be as well applied for soils and mixtures of aggregates. Indicator penetration testing is conducted in conditions similar to substrate work after its proper compaction; moreover, the CBR method of marking the indicator for material requires to conductit after four days of soaking, which simulates unfavourable conditions of water saturation. Unfortunately, the CBR test method is laborious and time consuming [22].

This article analyses the geotechnical and physical test results with particular consideration of CBR of mixtures of crushed aggregate assessed for their application in road construction as subgrade layer. An attempt was also made to find the correlation between CBR ratio and other physical properties. All aggregate tests were performed at 'Laboratorium Badania Własności Skał i Wyrobów Kamieniarskich AGH’ in Cracow.

\section{Requirements for substructure of crushed aggregate with continuous granulation}

The substructure is the lower part of road surface construction to transfer the load of vehicle to the ground base. Base substructure (single or double layer) and subbase. The subbase is a layer that enables proper integration of base substructure and protects the upper layers of road surface from the harmful influence of frost and uneven distribution of stress of vehicle wheels. Single layer base substructure is usually used for roads with a low load-bearing capacity of traffic ( from KR1 to KR3 class roads). Whereas, for the road surface from KR3 to KR7 class, it is required to use the double layer base substructure 
[23]. Material for substructure layer are mixtures of crushed-stone aggregates with continuous granulation up to the grain size of $63 \mathrm{~mm}$. The mixtures of aggregates can be of variable quality, which results both from wide variety of different rock properties and considerable discrepancy of rock material parameters within one bed rock. Moreover, the properties of aggregates particularly with continuous granulation are influenced by their geometrical properties. The parameters are evaluated based on the concentration in particular fractions and the shape of the grains. The base for obtaining the proper bearing of a given substructure is its compaction, that is, mechanical stabilization. The aggregate for mechanically stable substructure should be characterized by continuous granulation with proper curve located on the chart in the area of so-called proper granulation ( SDV lines in figure 1 and 2). It should guarantee that such a mixture will compact very well, and as a consequence, it will be characterized by high bearing ratio. The minimum value of bearing ratio for base substructure according to the technical requirements is $80 \%$, while for the subbase it is $60 \%$ [23] with the compaction index of the mixture of $I_{s}=1.0$.

The tests conducted by Sas et al. [19] on mixtures with specially prepared grain composition with fraction of $0 / 31$ $\mathrm{mm}$ of concrete rubble showed very good compaction and high CBR ratio, at the level of above $90 \%$ for material with optimum moisture and 78\%for material with fivefold compaction. According to the authors, the measure of good compaction of the mixture and its high ability to compact was non-uniformity graining coefficient $C_{U}$ and graining curve coefficient $C_{C}$, which for the prepared mixtures were respectively 54.55 and 1.52 .

According to PN-EN ISO 14688-2:2006 [4], the uniformity coefficient $C_{U}$ is marked as a ratio of substitute diameter of material grains at the amount of $60 \%$ and $10 \%$, as shown in equation (1):

$$
C_{U}=\frac{d_{60}}{d_{10}}
$$

where:

$d_{60}$-diameter corresponding to $60 \%$ finer in the particlesize distribution curve, $\mathrm{mm}$,

$d_{10}$-diameter corresponding to $100 \%$ finer in the particlesize distribution curve, $\mathrm{mm}$.

Whereas, the coefficient of gradation $C_{C}$ is calculated from equation (2):

$$
C_{C}=\frac{d_{30}^{2}}{d_{60} \cdot d_{10}}
$$

where: $d_{30}$-diameter corresponding to $30 \%$ finer, $\mathrm{mm}$.
Table 1: Ground characteristic according toPN-IS014688-2:2006 ${ }^{[4]}$ indicator.

\begin{tabular}{lll}
\hline Granulation & $\begin{array}{l}\text { Uniformity } \\
\text { coefficient } C_{u}\end{array}$ & $\begin{array}{l}\text { Coefficient of } \\
\text { gradation } C_{c}\end{array}$ \\
\hline Multiple fraction soil & $>15$ & $1-3$ \\
Moderate structure soil & $6-15$ & $<1$ \\
Even grain structure soil & $<6$ & $<1$ \\
Non-continuous structure soil & High value & Mostly $<0.5$ \\
\hline
\end{tabular}

On the basis of the value of these coefficients, the standard [4] specifies the soil types according to granulation and ability to compact well embankment or road embankment (Table 1).

It is usually assumed that only multiple fraction soil $\left(C_{v}>15\right.$ i $\left.1 \leq C_{C} \leq 3\right)$ can compact well and obtain high bearing ratio. However, the analysis carried out by Patakiewicza and Zabielska-Adamska [17] showed that non-cohesive soils with the above coefficients outside the scope of multiple fraction granulation may as well characterize by good compaction.

Tests conducted by Saklecha et al. [18] and Taha et al. [20] showed strong correlation between CBR ratio and particle-size distribution, optimum moisture content and maximum dry density. The more tightly are the aggregate grains in the sample, the higher are compaction and CBR bearing ratio. Such dependence makes sense only if the tested soil material has the same compaction and similar mineral composition of the rock.

Physical properties that are sand equivalent, water absorption, resistance to freezing and thawing, resistance to wear and fragmentation as well as geometric properties have high impact on substructure bearing ratio. Węgliński et al. [21] indicate that the fragmentation resistance Los Angeles test method may be an effective quality evaluation of material for road substructure. Assuming that the mixture grain composition will remain in the area of so-called good granulation and the value of the sand equivalent will remain at the level excluding the tendency to frost heave (SE should be at least 40 for subbase and 45 for base substructure). The value of sand equivalent is highly influenced by the grains of less than $0.063 \mathrm{~mm}$ content, the type of material that constitutes the aggregate [3]. Technical requirements [23] specify the least class of crushing resistance Los Angeles for the material used for subbase $L A_{40}$, whereas for the base substructure $L A_{35}$. 


\section{Geometrical and physical proper- ties of mixtures of crushed-stone aggregates}

Mixtures of crushed-stone aggregate are granulated materials obtained by the mechanical crushing of solid rock, and according to grain composition, they may be divided as sorted (classified) and so called unsorted. Mixtures are in a type of crushed-stone aggregates with continuous structure with the size of grains from 0 to maximum $63 \mathrm{~mm}$. Unfortunately, not all aggregates are suitable for road surface base, because they do not comply the basic requirements of the classification standards for particular units $[12,12,16,23]$.

Nine mixtures of crushed aggregate with $0 / 31.5 \mathrm{~mm}$ and $0 / 63 \mathrm{~mm}$ fractions were tested. The aggregate for the test came from different regions of southern Poland. Mixtures of crushed sandstone aggregate came from Klęczany and Lipowica quarries. Dolomite aggregates came from Dubie and Żelatowa quarries, whereas granite aggregate mixture came from Rogoźnica quarry, basalt from Winna Góra mine, limestone from Czatkowice mine, magnesia-serpentinite from Grochów quarry, and serpentinite aggregate from Nasławice mine. Tested mixtures significantly varied for their mineralogical and pectrographic type of rock material, which resulted in a wide variety of physical-mechanical properties of both material and the aggregate.

In mixture, with expected high bearing ratio, the share of particular grain fractions should be optimal. Too high content of grains of less than $0.063 \mathrm{~mm}$ and fine grains may not favour good bearing, and additionally, when soaked in water, such mixture may soften. While too high content of coarse grains may hinder proper compaction. The grain composition of aggregate mixtures to ensure uniformity and continuity must be in the area of so called good granulation and/or $C_{U}$ and $C_{C}$ should be within the area presented in Table 1. Figure 1 shows the curves of grain composition of the mixtures of $0 / 31.5 \mathrm{~mm}$, while Figure 2 shows the mixtures of $0 / 63 \mathrm{~mm}$. The curves of range of good granulation of material for subbase (as the ones with lower requirements) were additionally indicated on both figures [23]. Table 2 shows values of $C_{U}$ and $C_{C}$ coefficients (2) calculated based on grain composition and relation (1).

Analysing the curves of grain composition, only the limestone and dolomite aggregates from Żelatowa were within the area of good granulation SDV, according to [23] for the mixtures of $0 / 31.5$, while for the mixtures of $0 / 63 \mathrm{~mm}$, there were the aggregates of both sandstone and limestone. Analysing the values of uniformity coefficient

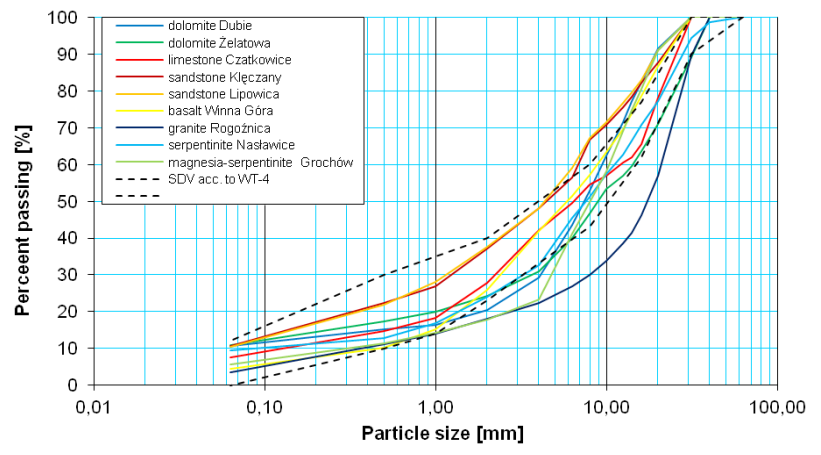

Figure 1: The curves of grain composition of the mixtures of $0 / 31.5 \mathrm{~mm}$ with the area of good granulation for subbase (SDV acc. to WT-4 [23]).

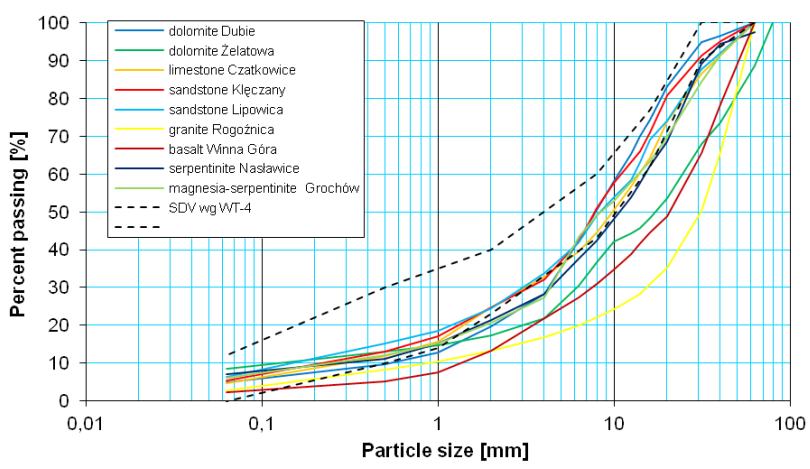

Figure 2: The curves of grain composition of the mixtures of 0-63 $\mathrm{mm}$ with the area of good granulation for subbase (SDV acc. to WT-4 [23]).

$C_{U}$ for all materials, it was above 15 , while the coefficient of gradation $C_{C}$ was in an extremely wide range. According to $[4,17]$, a dolomite from Dubie with fraction 0/63, a limestone and both basalt aggregate mixtures can obtain high compaction. Granulation of dolomite Dubie and basalt with fraction of $0 / 31.5$ is relatively close to the established range. However, granulation of basalt mixture with fraction of $0 / 63 \mathrm{~mm}$ show completely different results.

Table 2 summarises the remaining physical properties of the tested mixtures of the aggregates. The tests were performed according to the applicable testing standards (Table2) selected on the basis of the standards and requirements of the qualification standard for unbound aggregate mixtures [13]. Volcanic rock with the exception of granite mixtures for which the $L A$ was above 30 , characterized with the highest values of mechanical parameters of aggregates tested for crushing and abrasion. Limestone of Czatkowice and dolomite of Dubie mine from the sedimentary rock type characterized with very good properties. Both types of tested sandstone and dolomite from Żelatowa were materials with the lowest values of mechanical parameters, which is mostly demonstrated by 


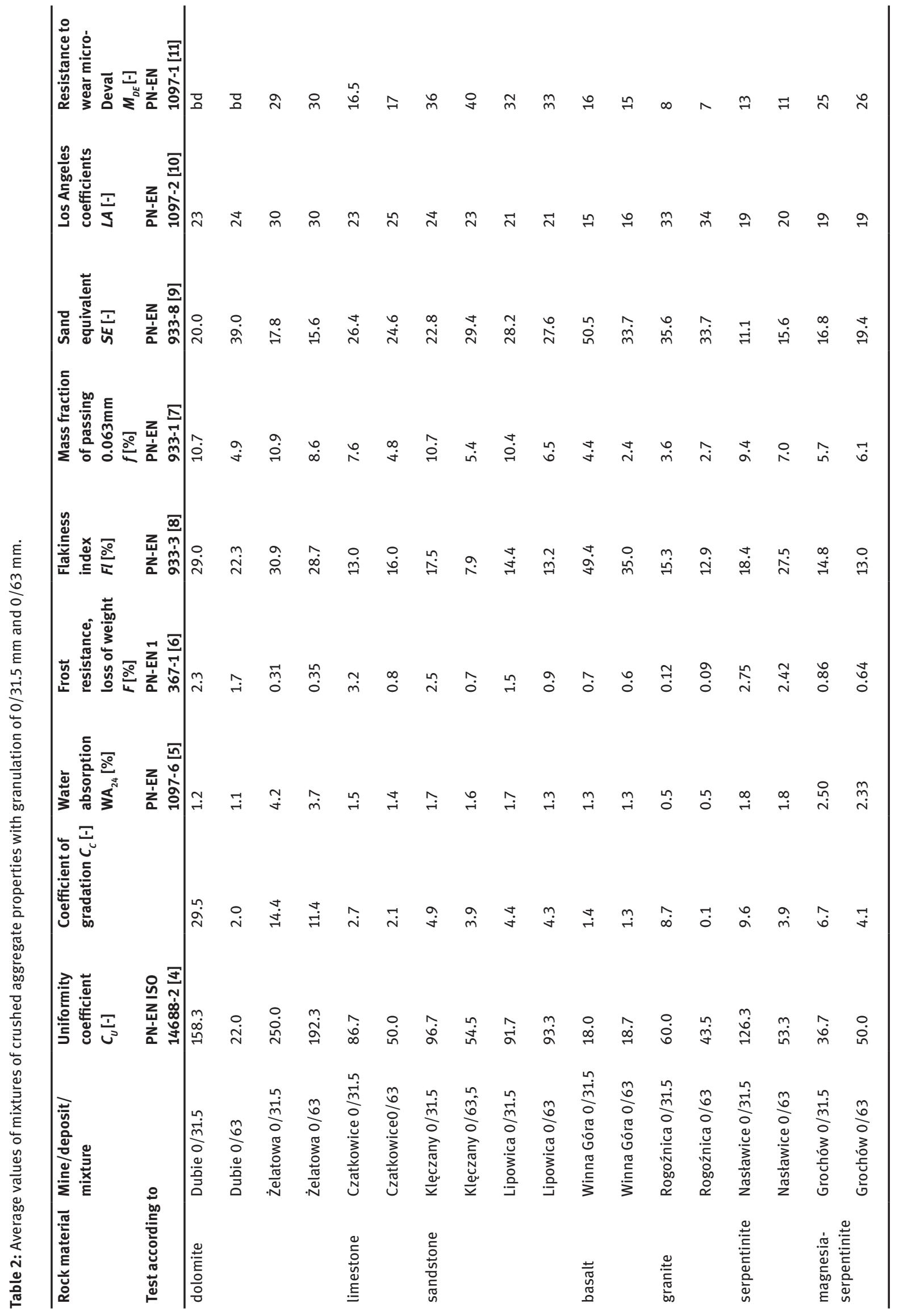


Table 3: Optimum moisture content and maximum dry density for tested samples.

\begin{tabular}{|c|c|c|c|c|c|}
\hline \multirow[t]{2}{*}{ Type of aggregate } & \multirow[t]{2}{*}{ Mine } & \multicolumn{2}{|l|}{ Mixture of $0 / 31.5 \mathrm{~mm}$} & \multicolumn{2}{|l|}{ Mixture of $0 / 63 \mathrm{~mm}$} \\
\hline & & $\begin{array}{l}\text { Optimum moisture } \\
\text { content [\%] }\end{array}$ & $\begin{array}{l}\text { Maximum dry density } \\
{\left[\mathrm{g} / \mathrm{cm}^{3}\right]}\end{array}$ & $\begin{array}{l}\text { Optimum moisture } \\
\text { content [\%] }\end{array}$ & $\begin{array}{l}\text { Maximum dry density } \\
{\left[\mathrm{g} / \mathrm{cm}^{3}\right]}\end{array}$ \\
\hline \multirow[t]{2}{*}{ dolomite } & Dubie & 5.8 & 2.205 & 6.2 & 2.155 \\
\hline & Żelatowa & 6.3 & 2.066 & 5.6 & 2.040 \\
\hline limestone & Czatkowice & 4.4 & 2.190 & 7.1 & 2.240 \\
\hline \multirow[t]{2}{*}{ sandstone } & Klęczany & 6.4 & 2.290 & 5.0 & 2.360 \\
\hline & Lipowica & 6.8 & 2.280 & 4.8 & 2.390 \\
\hline basalt & Winna Góra & 6.5 & 2.230 & 3.9 & 2.223 \\
\hline granite & Rogoźnica & 3.1 & 2.080 & 6.5 & 2.052 \\
\hline serpentinite & Nasławice & 4.3 & 1.962 & 4.6 & 2.050 \\
\hline $\begin{array}{l}\text { magnesia - } \\
\text { serpentinite }\end{array}$ & Grochów & 6.9 & 2.020 & 7.3 & 1.980 \\
\hline
\end{tabular}

low abrasion resistance. In spite of the high $L A$ resistance values, all the materials were technically suitable for substructure.

Material approved for road surface layers, according to WT-4 [23], should characterize with absorbability of maximum $2 \%$ and loss of weight of aggregate after 10 freeze/thaw cycles in water of not more than $4 \%$. The value of absorbability was exceeded only for the mixtures of dolomites from Żelatowa and magnesia-serpentinite aggregate. Despite a relatively high value of absorbability, none of the materials showed loss of weight of boundary value of $4 \%$. The highest loss of weight was noticed for the dolomite from Dubie, limestones and serpentinite; while in the other cases, the values did not exceed $1 \%$ of aggregate weight. The evaluation of material sensitivity to the frost was tested on the basis of sand equivalent $S E$. Table 2 shows $S E$ values for fivefold material compaction. Analysing the tested mixtures, only basalt mixture of 0/31.5 $\mathrm{mm}$ has a sand equivalent at the level of $S E=50$ and is suitable for substructure. Other mixtures, while constituting the road surface, may show a tendency for destruction in frosty conditions. While analysing mixtures for grains below $0.063 \mathrm{~mm}$ content, only the dolomite mixtures with fraction 0/31.5 from Dubie and Żelatowa do not comply with the requirements for base substructure(maximum content of $9 \%$ ) but only for subbase (maximum content of up to $12 \%$ ).

\section{Values of CBR ratio for mixtures of $0 / 31.5 \mathrm{~mm}$ and $0 / 63$}

Indicator penetration test to establish the bearing ratio is performed on the compact material ( $I s=1.0$ ) with optimum moisture content according to the standards PN-EN 13286-47:2007 [15]. In connection with the fact that granulation of the tested material was $0 / 31.5 \mathrm{~mm}$ and $0 / 63$ $\mathrm{mm}$ and the applied method of testing CBR ratio relates to the material with a maximum dimension of $22.5 \mathrm{~mm}$, the samples were supposed to be properly prepared. Method standards PN-S 06102:1997 [16] were used for this purpose, and for each material, grains above $20 \mathrm{~mm}$ were screened out and replaced with an equivalent material of dimension from $6.3 \mathrm{~mm}$ to $20 \mathrm{~mm}$. An American method AASHTO Designation T 193-99 [1] has also similar requirements concerning material preparation, according to which, the grains above $19 \mathrm{~mm}$ are replaced with material of 4.75/19 $\mathrm{mm}$. Material prepared in such a way was tested both for optimum moisture and CBR ratio. Mixtures of crushed aggregates were compacted according to the Proctor method standards PN-EN 13286-2:2010 [14]. Compaction of the aggregates was done in three layers with $2.5 \mathrm{~kg}$ rammer (rammer A) in a big mould (B) of a diameter 150 $\mathrm{mm}$ and height of $120 \mathrm{~mm}$. Table 3 summarises the values of optimal moisture and maximum dry density for all the tested aggregate samples.

Next, the mixtures of aggregates were tested for CBR indicator directly after concentration of the material in cylinder and after four days of water soaking. Table 4 summarises the average values of bearing ratio of mixtures of aggregates, obtained from the test of at least two identical samples. 
Table 4: Values of CBR ratio for mixtures after compaction and after four days of soaking in water.

\begin{tabular}{llllll}
\hline Type of aggregate & Mine & $\begin{array}{l}\text { Mixture of 0/31.5 } \mathbf{~ m m} \\
\text { CBR directly after } \\
\text { compaction [\%] }\end{array}$ & $\begin{array}{l}\text { CBR after four days of } \\
\text { soaking in water [\%] }\end{array}$ & $\begin{array}{l}\text { Mixture of 0/63 mm directly after } \\
\text { Compaction [\%] }\end{array}$ & $\begin{array}{l}\text { CBR after four days of } \\
\text { soaking in water [\%] }\end{array}$ \\
\hline Dolomite & Dubie & 39.6 & 30.9 & 26.0 & 24.1 \\
& Żelatowa & 29.5 & 22.7 & 23.2 & 21.0 \\
Limestone & Czatkowice & 47.0 & 24.8 & 31.2 & 29.6 \\
Sandstone & Klęczany & 37.6 & 34.2 & 43.3 & 36.9 \\
& Lipowica & 34.3 & 28.8 & 51.0 & 49.8 \\
Basalt & Winna Góra & 42.3 & 38.7 & 40.1 & 37.0 \\
Granite & Rogoźnica & 37.7 & 41.5 & 18.1 & 20.1 \\
serpentinite & Nasławice & 51.7 & 40.3 & 59.6 & - \\
magnesia-serpentinite & Grochów & 36.5 & 33.2 & 43.2 & 31.1 \\
\hline
\end{tabular}

It can be noted that the highest values of bearing ratio directly after compaction of above $50 \%$ are for serpentinite aggregate mixtures both of $0 / 31.5$ and $0 / 63$ $\mathrm{mm}$ and for sandstone mixture of $0 / 63$ from Lipowica. This is due to the fact that the granulation is proper. High CBR values may be as well expected for dolomite mixture of 0/31.5 from Żelatowa due to good granulation. However, it has the lowest bearing ratio, which may be resulting from low crushing and abrasion resistance and high content of flat and irregular grains. It could have been also expected to obtain high values of bearing for aggregate samples of volcanic rock with high mechanical parameters, that is, basalt and granite. In both the cases, the reason for obtaining low values of bearing ratio was improper grain composition, in spite of the fact that $C_{U}$ and $C_{C}$ coefficients for basalt showed high suitability for compaction. However, the modification of grain composition caused a sudden increase in the content of grains above $6.3 \mathrm{~mm}$ and modification of $C_{U}$ and $C_{C}$ coefficients. An increase of the curves of grain composition coefficient $C_{C}$ and decrease of graining curve coefficient $C_{U}$ occurred in most cases. This may indicate that mixtures prepared in such way are more difficult to compact and at the same time, it is harder to obtain a high value of CBR ratio. Additional reason for low values of bearing ratio in case of basalt mixtures was high content of irregular grains, and in case of granite mixtures, low crushing resistance. None of the tested mixtures complied the required minimum values of bearing ratio.

Values of CBR ratio after water soaking in case of most analysed samples decreased at a very large range from few percent to even over $20 \%$. It was caused mostly by an increase of material moisture, softening and the change of consistency. Only the mixtures of granite after compacted material saturation showed an increase of CBR with an increase of moisture by about $0.5 \%$.

\section{Analysis of an influence of geometrical and physical properties on CBR ratio}

The correlation dependencies between CBR ratio and other aggregate parameters were specified to state which geometrical and physical properties of aggregates have the highest influence on obtaining high compaction, which means high substructure or subbase layers' bearing. Mechanical properties of aggregates, that is, resistance to fragmentation $L A$ were tested first. Linear correlation between the value of CBR ratio and $L A$ coefficients (Fig. 3) was observed. It is clear to notice that lower the crushing resistance, lower is the CBR ratio. It means that aggregate grains with $L A$ coefficient of above 35 may get damaged by compaction. However, there is practically no influence on abrasion resistance values of CBR ratio for aggregates (Fig. 4).

Second part of proprieties analysed for CBR values are geometrical properties represented by the uniformity coefficient $C_{U}$ and coefficient of gradation $C_{C}$. Figures 5 and 6 show charts of correlation between bearing ratio and respectively $C_{U}$ and $C_{C}$. Presented correlation does not directly show the influence of coefficients connected with the mixture of aggregate granulation on CBR value, which 


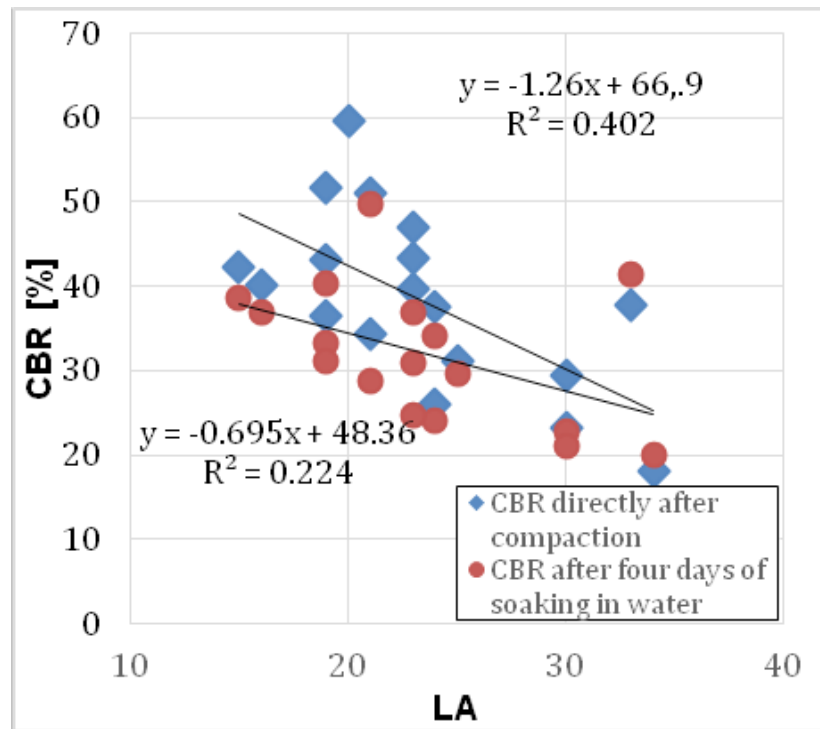

Figure 3: Correlation between CBR and Los Angeles coefficie.

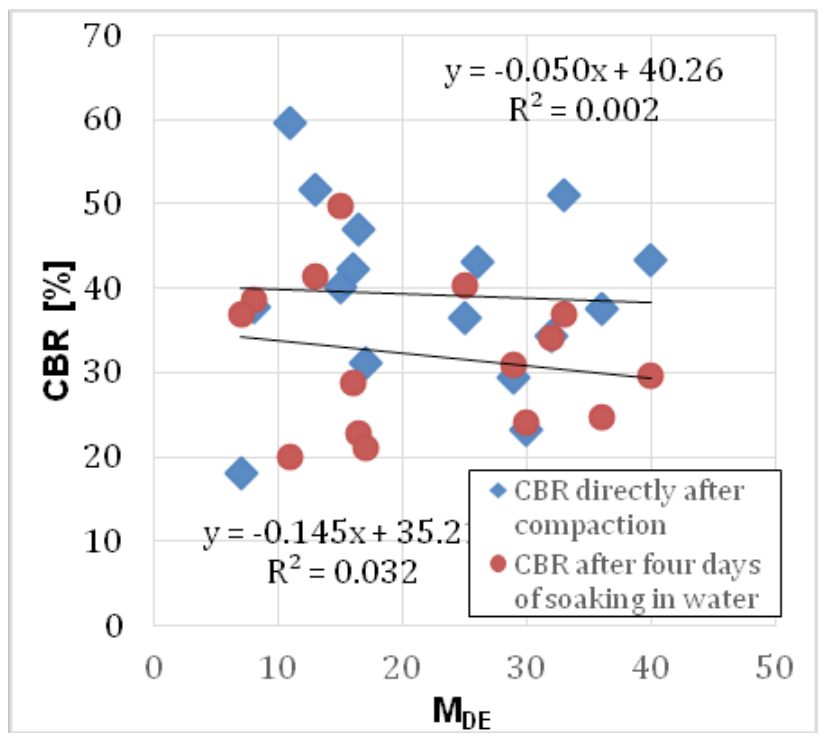

Figure 4: Correlation between CBR and micro Deval coefficient, values.

directly influences the bearing of substructure layers. These coefficients help only to evaluate the aggregate mixture ability to compact and obtain tight structure. However, there is only a complete consistency of limestone aggregate mixtures to the recommended grain content [23] for the substructure, while comparing the values of $C_{U}$ and $C_{C}$ (Table 2) coefficients.

The last part of analysed properties are parameters of compacted mixture prepared to the established CBR ratio. The parameters are optimum moisture content (Fig. 7) and maximum dry density (Fig. 8).

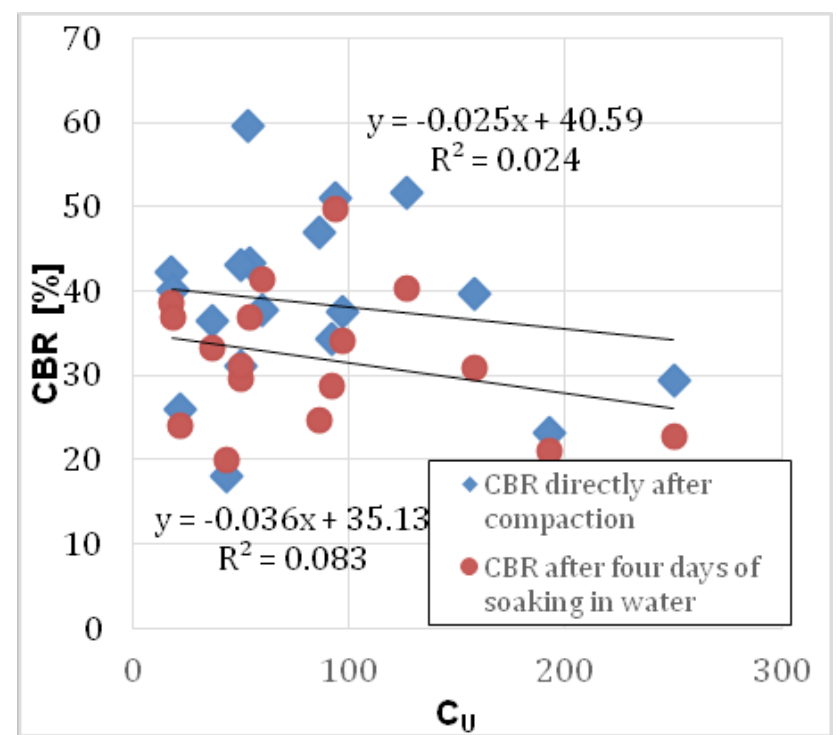

Figure 5: Correlation between CBR value and uniformity coefficient $C_{u}$ value.

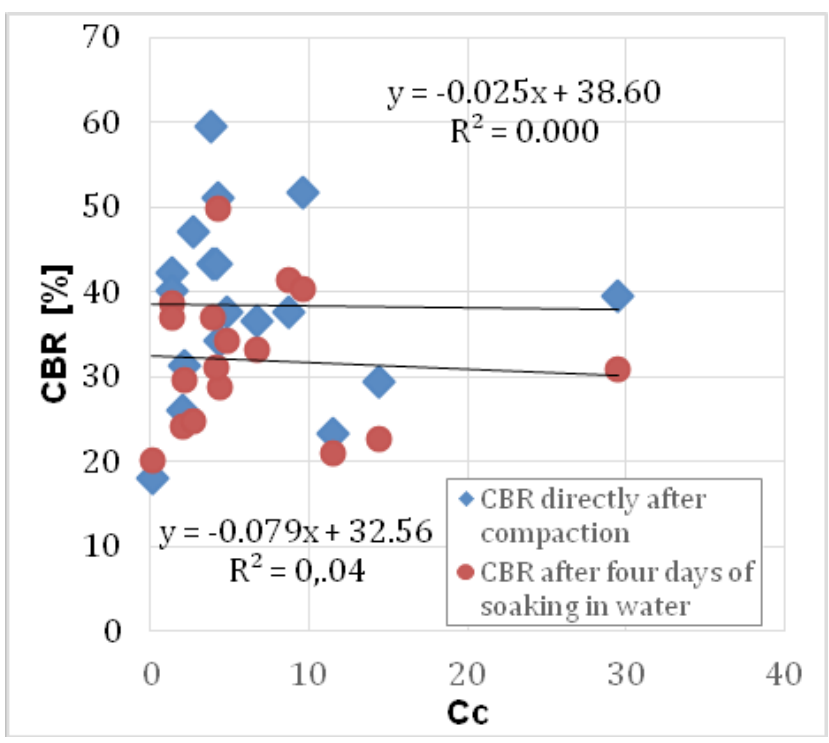

Figure 6: Correlation between CBR value and coefficient of gradation $C_{c}$ value.

The charts in figures 7 and 8 show a symptomatic tendency that lower the optimum moisture content of compacted mixture, higher is the value of bearing ratio The optimum moisture content in the mixture required to its maximum compaction is connected mostly with water demand of particular grains and its grain content. The lower the fraction, more is the water it requires to properly moisture the grains. The less popular tendency is to notice, for relation to maximum compaction of soil skeleton. It means that the level of grains' content, moisture, and volume density influence the volume of 


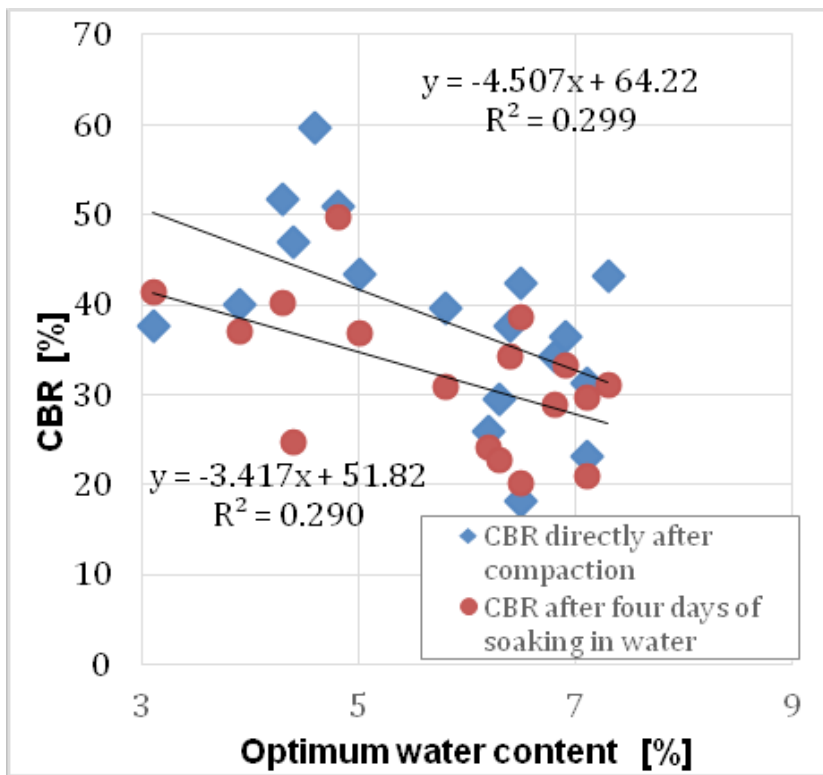

Figure. 7: Correlation between CBR value and optimum moisture content value.

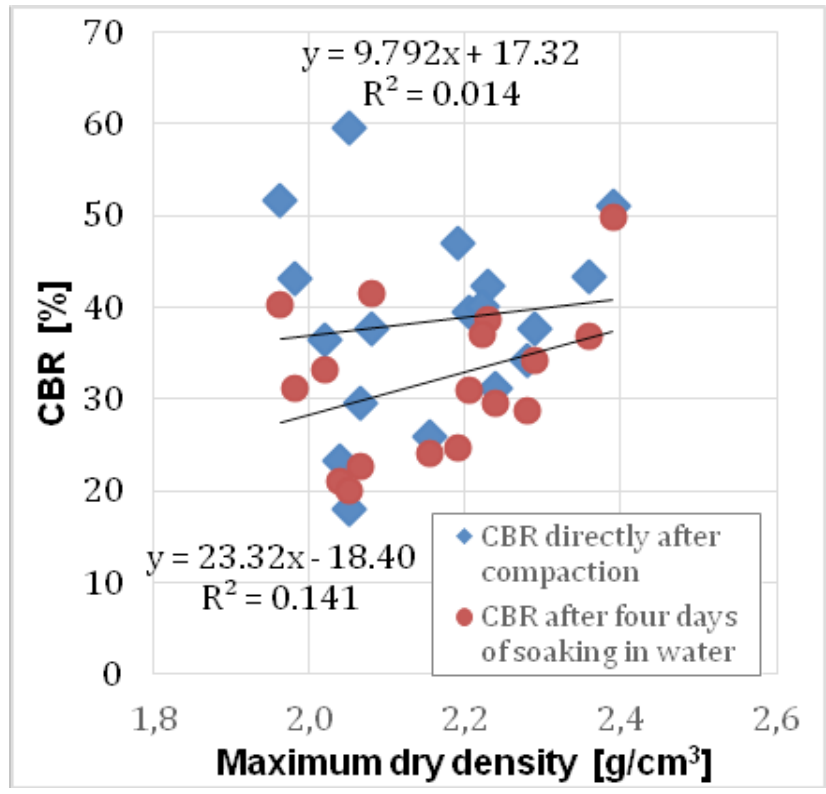

Figure 8: Correlation between CBR value and maximum dry density.

mixture density after compaction. However, higher the density, higher is the CBR. The similar results of statistical analysis were obtained in studies [18], [20]. The coefficient of determination $R^{2}$ in case of the influence of optimum moisture content was at the similar level, but to obtain maximum dry density of soil it was $R^{2}=0,464$ [10] and $R^{2}$ $=0,848$ [20]. It is to note that in both cases, the samples were taken from soil substructure of road construction.
The remaining physical and geometrical parameters of aggregates indirectly influenced the substructure bearing, but for such different mineralogical-petrographic aggregates, it is difficult to evaluate. Series of tests of multiple identical samples of aggregates of one rock type should be performed.

\section{Conclusion}

Mixtures of crushed rock aggregate with continuous grain are widely used for digging and road construction. However not all types of aggregates are properly prepared and suitable for this kind of work. Nine types of crushed rock aggregate with continuous grain of fraction $0 / 31.5$ $\mathrm{mm}$ and $0 / 63 \mathrm{~mm}$ from different bed rocks were tested. On the basis of the results of analysis of comprehensive tests of the mixture, the following conclusions were reached:

- Values ofCBR ratio were in a wide range from about 20 to $60 \%$. None of the tested mixtures complied to the required minimum bearing ratio for road substructure.

- The aggregate of rock with high mechanical properties is not always a suitable material for road surface construction. The grain content of crushed aggregate will have a substantial influence on bearing ratio.

- Uniformity coefficient $C_{U}$ and coefficient of gradation $C_{C}$ constitute a quick way of establishing the mixtures' suitability for compaction. However, it is not possible to clearly state if the mixture with low suitability for compaction will characterize with low bearing and vice versa.

CBR ratio test, according to PN-EN 13286-47:2007, refers to the material that entirely passes through a sieve of $22.5 \mathrm{~mm}$. Unfortunately, there is no precise information concerning the preparation method of the sample, nor how to interpret the results of the tests for aggregates containing bigger grains. PN-S-06102:1997 and AASHTO T 193-99 (2003) methods present the way of sample modification but do not explain how the modification of grain composition influences CBR ratio.

\section{References}

[1] AASHTO Designation T 193-99 (2003) Standard Method of Test for The California Bearing Ratio

[2] Gonzalez C. R., Barker W. R., Bianchini A. Reformulation of the CBR Procedure Report II: Design, Construction, and Behavior 
Under Traffic of the Pavement Test Sections. US Army Corps of Engineers Washington, DC 2013.

[3] Piech R., Wilczek J., Kraszewski C., Ocena zawartości drobnych czastek w kruszywach drogowych na podstawie wskaźnika piaskowego, Drogownictwo, 2015, 2, 53-56.

[4] PN-EN ISO 14688-2:2006 Badania geotechniczne -- Oznaczanie i klasyfikowanie gruntów -- Część 2: Zasady klasyfikowania

[5] PN-EN 1097-6:2013 Badania mechanicznych i fizycznych wtaściwości kruszyw - Część 6: Oznaczanie gęstości ziarn i nasiąkliwości

[6] PN-EN 1367-1:2007 Badania właściwości cieplnych i odporności kruszyw na działanie czynników atmosferycznych -- Część 1: Oznaczanie mrozoodporności

[7] PN-EN 933-1:2012 Badania geometrycznych właściwości kruszyw -- Część 1: Oznaczanie składu ziarnowego -- Metoda przesiewania

[8] PN-EN 933-3:2012 Badania geometrycznych właściwości kruszyw -- Część 3: Oznaczanie kształtu ziarn za pomocą wskaźnika płaskości

[9] PN-EN 933-8:2012 Badania geometrycznych właściwości kruszyw -- Część 8: Ocena zawartości drobnych cząstek -Badanie wskaźnika piaskowego

[10] PN-EN 1097-2:2010 Badania mechanicznych i fizycznych właściwości kruszyw -- Część 2: Metody oznaczania odporności na rozdrabnianie

[11] PN-EN 1097-1:2011 Badania mechanicznych i fizycznych właściwości kruszyw -- Część 1: Oznaczanie odporności na ścieranie (mikro-Deval)

[12] PN-EN 13285:2010 Mieszanki niezwiązane - Specyfikacja.

[13] PN-EN 13242:2010 Kruszywa do niezwiązanych i związanych hydraulicznie materiałów stosowanych w obiektach budowlanych i budownictwie drogowym.

[14] PN-EN 13286-2:2010 Mieszanki niezwiązane i związane hydraulicznie -- Część 2: Metody badań laboratoryjnych gęstości na sucho i zawartości wody -- Zagęszczanie metoda Proktora.
[15] PN-EN 13286-47:2007 Mieszanki niezwiq̨zane i zwiqzzane spoiwem hydraulicznym -- Część 47: Metoda badania do określenia kalifornijskiego wskaźnika nośności, natychmiastowego wskaźnika nośności i pęcznienia liniowego.

[16] PN-S-06102:1997 Drogi samochodowe -- Podbudowy z kruszyw stabilizowanych mechanicznie.

[17] Potakiewicz M., Zabielska-Adamska K., Wskaźnik krzywizny uziarnienia a parametry zagęszczalności gruntów niespoistych o dwumodalnych rozkładach uziarnienia. Architectura. 2013, 12 (3), 111-123.

[18] Saklecha P.P., Katpatal Y.B., Rathore S.S., Agarawal D.K., Spatial Correlation of Mechanical Properties of Subgrade Soil for Foundation Characterization. International Journal of Computer Applications. 2011, 36(11), 20-25.

[19] Sas. W., Szymański A., Malinowska E., Gabryś K. Geotechniczne uwarunkowania zastosowania materiatów antropogenicznych w budownictwie. Inżynieria Morska i Geotechnika. 2014, 4, 376-389.

[20] Taha S., El-Badawy S., Gabr A., Azam A., Shahdah U., Modeling of California Bearing Ratio using Basic Engineering Properties. 8th International Engineering Conference, At Sharm Al-Sheikh, Egypt. https://www.researchgate.net/publication/305725330_ Modeling_of_California_Bearing_Ratio_using_Basic_ Engineering_Properties

[21] Węgliński S., Babiak M., Ratajczak A., Porównanie wybranych cech kruszyw tamanych i recyklingowych stosowanych $w$ budownictwie wg norm zharmonizowanych. Archives of Institute Of Civil Engineering, 2017, 24, 369-384

[22] Witun Z. Zarys geotechniki. Wydawnictwo komunikacji i Łączności wydanie czwarte, Warszawa 2000.

[23] WT-4. Wymagania techniczne. Mieszanki niezwiązane do dróg krajowych. GDDKiA, Warszawa 2010 